\title{
Coastal and deep deformations of the riverbed in the area of a damless water intake
}

\author{
Dilshod Bazarov ${ }^{1}$, Irina Markova ${ }^{2}$, Sanatjon Khidirov ${ }^{1}$, Oybek Vokhidov ${ }^{1 *}$, Farokhiddin \\ Uljaev $^{1}$, and Ikboloy Raimova ${ }^{1}$ \\ ${ }^{1}$ Tashkent Institute of Irrigation and Agricultural Mechanization Engineers, 100000, Tashkent, \\ Uzbekistan \\ ${ }^{2}$ Moscow State University of Civil Engineering, Yaroslavskoe shosse, 26, Moscow, 129337, Russia
}

\begin{abstract}
The paper analyzes the dynamics of planned and deep deformations on the section of the Amudarya River in the area of the damless water intake in the main structure of the Karshi Main Canal-KMC. The results of field studies of the state of the canal situation of the Amudarya River at the site of a damless water intake are studied. The course of riverbed processes in the riverbed is studied. Recommendations for improving water intake conditions have been developed. According to the results of the field survey and the study of the head section of the supply canal, the state of the Amudarya riverbed in the water intake zone was assessed. The results of surveys of the hydraulic and pumping modes of sediments of the Amudarya River in the area of the damless water intake are analyzed and summarized. The results of field studies of the canal situation of the Amudarya River in the water intake area in the Amudarya River KMC in the area of the Karshi head water intake are studied. The riverbed situation is not characterized by constant hydraulic characteristics over time for the same water flow rate, i.e. with the same water horizon marks, the flow rates may differ from each other by about half, and with the same flow rates, the horizon marks may vary up to $\pm 0.6 \mathrm{~m}$. This is explained by the extreme instability and high mobility of the canal, and large deformations of the canal occur in a short time. The hydraulic regime of the river is characterized by a significant redistribution of speeds, depth and width of the flow. The range of their changes is within: Maximum speed $V_{\max }=2 \ldots .5 \mathrm{~m} / \mathrm{s}$; average speed $V_{a v}=0.5 \ldots 2.5 \mathrm{~m} / \mathrm{s}$; depth $H_{\max }=4 \ldots 14 \mathrm{~m}, H_{a v}=1 . .5 \mathrm{~m}$; width $B=300 \ldots .2000 \mathrm{~m}$; slope $i=0.00016 \ldots 0.0003$. It is established that the characteristic feature of the river is that at a constant flow can have different average velocities depth and width, for example, when $Q_{w}=1000 \mathrm{~m} 3 / \mathrm{s}$, respectively, $v=$ $0.6 \ldots 1.7 \mathrm{~m} / \mathrm{s}, B=180 \ldots 1030 \mathrm{~m}, H_{a v}=1.1 \ldots 4.3 \mathrm{~m}$.
\end{abstract}

\section{Introduction}

The change in the hydrological regime of the river under the influence of water intake or

\footnotetext{
${ }^{1 *}$ Corresponding author: vohidov.oybek@bk.ru
} 
flow inflow to the river is accompanied by intense riverbed deformations. This phenomenon is pronounced occurs if the riverbed passes through easily eroded soils. Such a change in the riverbed very often in the practice of hydraulic structures generates serious operational problems. Such a change in the riverbed very often in the practice of hydraulic structures generates serious operational problems. The parts of the river Amudarya where the damless intake headworks Karshi Main Canal-KMC refers to the parts of the river where riverbed irreversible deformation, the intensity of which adversely affect the operational mode of the Brain structures in the KMC. The main water intake structure in the a KMC is located on the stable shore of Cape Pulizin with a supply canal 21 kilometers long upstream from the hydropost of the city of Kerki in the Republic of Turkmenistan. The Amudarya River is characterized as a river with a wandering canal [1-3]. During water intake from the Amudarya River to the Karshi main canal, difficulties arise due to rapid siltation, sediment deposition of the head section of the canal and erosion of the opposite bank of the river from the water intake point. Depending on the water content of the year, a stream with a turbidity of up to $5 \mathrm{~kg} / \mathrm{m} 3$ enters the inlet part of the canal annually. Annual sediment volumes ranged from 7 to 14 million tons [4-6]. Due to the existing engineering problems, the above complex is chosen as the object of research of this work.

In the course of the Amudarya River, the largest head structures with a damless water intake have been built. These include the head structures: the Amuzang, Jaihun, Karakum, Karshi Main and Amu-Bukhara machine canals [4-9]. When water is taken from the river, there is a quantitative and qualitative change in the flow characteristics. In addition, the riverbed situation in the water intake area is rapidly changing. Increases the character of the intensity of canal deformations of the river. All this significantly changes the natural course of the riverbed process, which leads to a deterioration of the water intake conditions in the head structure. To improve the operating conditions, first of all, a forecast of this process is required. To do this, it is necessary to have an idea of the deep and coastal deformations in the riverbed at the site of the water intake to the head of the structure. According to the above, we can state the relevance of the research of this work.

As is known, the riverbed process has a general stability, which is expressed in the fact that with an increase or decrease in the amount of bottom and suspended sediments that take the river out of the state of dynamic equilibrium, there is such an internal restructuring of the flow, canal and floodplain, in which the dynamic equilibrium is restored. In other words, the river has the ability to change its transport capacity within a very wide range, depending on the volume of solid flow given to it. This is achieved by changing the tortuosity of the canal (slope), the shape of the cross-section and the content of suspended sediments in the bottom sediments. The problem of studying and developing the theory of riverbed processes, coastal and deep deformations of the riverbed under the influence of water intake structures, quantitative and qualitative changes in riverbed flows has always attracted the attention of scientists around the world [10-13]. As a result of theoretical, experimental and field studies, the most important regularities of the flow, hydraulic resistance and development of the canal process for the natural state of the river, the influence on their intensity and direction are established. In many works, the theory of the attraction of bottom and suspended sediments is significantly covered, in which the gravitational theory of the movement of suspended sediments and the theory of the ridge movement of sediments were proposed and developed. From the standpoint of the method of dimension analysis, they proposed and justified a variety of models for calculating the movement of entrained sediments.

From the standpoint of the method of dimensional analysis, various models for calculating the movement of entrained sediments were proposed and justified [14].

However, despite the abundance of works devoted to this problem, its solution is still far from practical completion [15]. The reason for this is the complexity and multifactorial 
nature of the course of riverbed processes in space and time. Especially great difficulties arise in the design and operation of damless water intakes in rivers, the canal of which, due to large bottom slopes, high flow rates and easy erosion of bottom sediments (represented by fine-sanded weak soils), is subject to extremely complex intensive planned and deep deformations. The object of study of this work is located in the bed of the Amudarya River, which flows through easily eroded soils and corresponds to the above description [16].

The intensity of riverbed deformations strongly affects the working conditions of the head structure of the Karshi Main Canal [17]. To improve the water intake conditions and ensure the flow of high-quality flow with the lowest turbidity to the head structure, a thorough study of the canal deformations and their nature in the study area is required.

Therefore, the analysis of the results of field studies to determine the intensity of the deep and coastal deformation of the Amudarya river in district headwork damless water intake and on the basis of the obtained results to develop recommendations for improving its operation is defined as the main goal of the present work.

\section{Methods}

The study and comparison of the results of the field studies of canal deformation at the site of the Amudarya river in district headwork damless intake in Karshi Main Canal and assessment of the river bed of the Amudarya river in the catchment area is the research method of this work.

\section{Results and Discussion}

Drastic climate change, respectively, the hydrological regime of the river and the construction of various hydraulic structures in the upper reaches of the Amudarya are increasingly affecting the optimal operation of the head structure of the damless water intake into the Karshi Main Canal. Year after year, there is a deterioration in the conditions of guaranteed water intake and a decrease in the possibility of taking water with the least entrained and suspended sediments. Even the beginning of the 70 years, on the basis of studies of canal processes and predictions of phenomena "degish", direction regalia events have damless intakes Department of canals SANIIRI was introduced the concept of the three major periods in the lives of rivers: Amudarya available (domestic) conditions; a period of increasing water withdrawal for irrigation and partial flow regulation and a period of complete regulate of the Amu Darya.

The present rivers of development belong to the second period.

More difficulties with ensuring water intake arise during the low-water period, when the water level in the river is low. A difficult situation has arisen at the head structure of the damless water intake to the Karshi Main Canal (KMC), in the head of which there is no control structure, and the operating mode of the first pumping station was developed for the conditions of the dam water intake at the Kyzylayak section. Due to the change in the geopolitical situation in the region, the Kyzylayak dam was not built, therefore, the condition of water intake into the head structure of the KMC became a very difficult task for hydraulic engineers. A sharp change in the hydrological regime of the river, due to the regulation of its upper course, further complicates the conditions for water intake into the head structure.

In order to study the intensity of the riverbed re-formation in the area of the damless water intake in the KMC and to develop measures to maintain a stable water intake during the low-water period (October), planned surveys of the riverbed above $(3 \mathrm{~km})$ and below $(2$ $\mathrm{km}$ ) the water intake point were carried out for several years (Fig.1). 


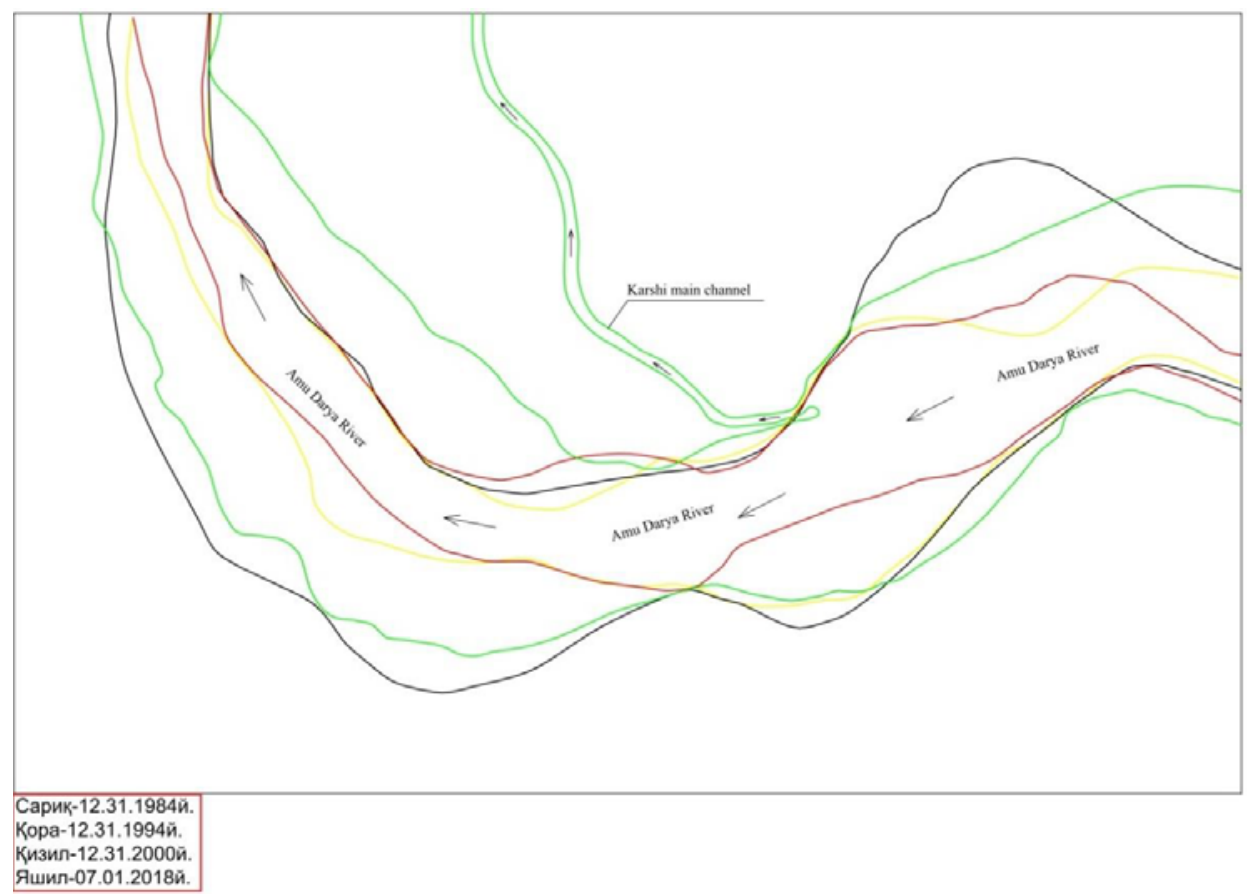

Fig. 1. Dynamics of planned deformations of the Amudarya River in the area of the head structure of the KMC.

The satellite images of the water intake area in the $\mathrm{CMC}$ for the last 10 years for the period from 1984-2018 were compared.

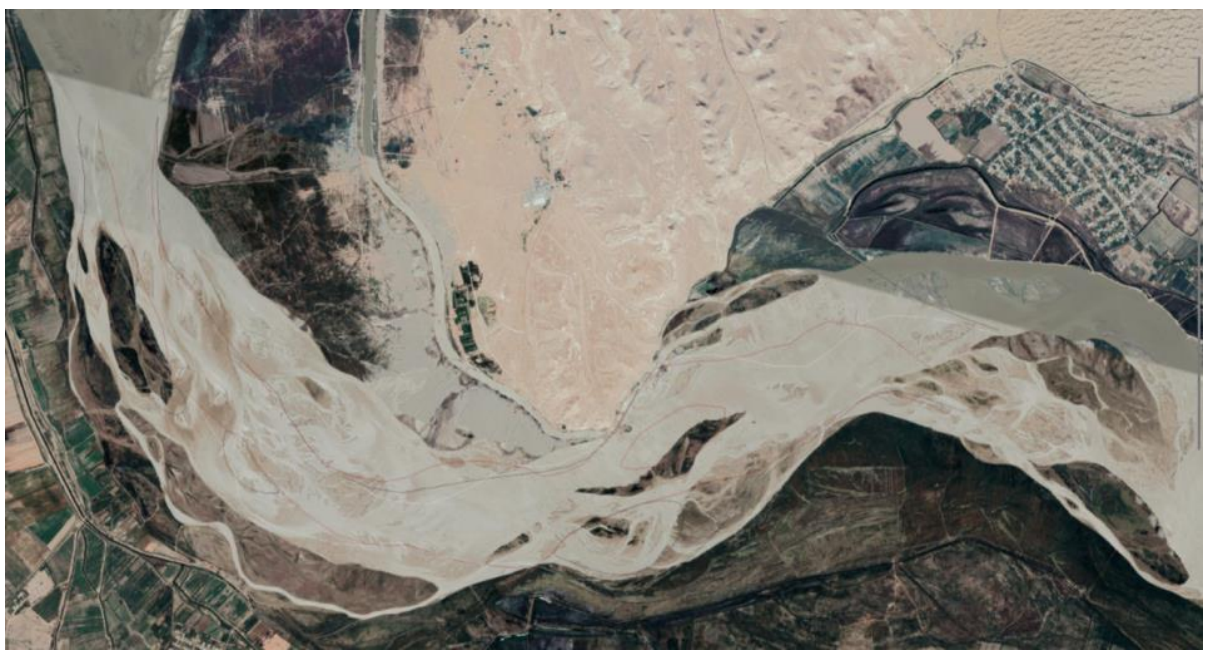

Fig. 2. Dynamics of the planned deformations of the Amudarya river in the area of the KMC head structure during the 1984 low-water period.

The Amudarya River in the area of the KMC head structure differs in the inconsistency of hydraulic characteristics over time for the same water flow rate, i.e. at the same water level, the discharge can differ from each other by about two times, and at the same discharge, the horizon level can fluctuate up to $\pm 0.6 \mathrm{~m}$. This is explained by the extreme instability and 
high mobility of the canal, and large canal deformations occur in a short time. The river's hydraulic regime is characterized by a significant redistribution of velocities, depth and width of the flow. The range of their change is within:

- maximum speed $V_{\max }=2 . .5 \mathrm{~m} / \mathrm{s}$;

- average speed $V_{a v}=0.5 \ldots 2.5 \mathrm{~m} / \mathrm{s}$;

- depth $H_{\max }=4 \ldots 14 \mathrm{~m}, \mathrm{H}_{a v}=1 \ldots .5 \mathrm{~m}$;

- width $B=300 \ldots 2000 \mathrm{~m}$;

- slope $i=0.00016 \ldots 0.0003$.

A characteristic feature of the river canal is that at a constant flow rate there can be different values of the average velocities of the depth and width of the canal, for example, at $Q_{w}=1000 \mathrm{~m} 3 / \mathrm{s}$, respectively, $V=0.6 \ldots 1.7 \mathrm{~m} / \mathrm{s}, B=180 \ldots 1030 \mathrm{~m}$, $H_{a v}=1.1 \ldots 4.3 \mathrm{~m}$.

It should be noted that the greatest values of average velocities and depths at any water flow rate fluctuate on curved sections of the canal, the smallest - on rectilinear sections, and the width of the canal, on the contrary, is greatest - on rectilinear sections, and the smallest - on curved sections. With an intensive increase in water intake, the overload of the river flow below the water intake section, due to private discharge of sediments during cleaning into the river floodplain and the intensive wandering of the flow, and thereby partially affects the displacement of the main flow to the left bank, as a result of the above phenomena, leads to a change in the plan, displacements of the Amudarya canal profile in the area of damless water intakes and in areas of intense erosion.

We compared the displacements of the main river bed in a wide floodplain and the planned changes in the Amudarya river bed for the period from 1980 to 1986. and satellite imagery 2010-2020. on the section of the Amudarya river in the area of intensive erosion of the coastal area of the village. Kyzylayak. Here there is a drop off with the current and coastal erosion (deigish), with the flow of the main stream often directed along the left bank strip, where the cultural lands of the Kyzylayak gauging station are located.

In addition, it should be noted that the wandering of the main canal of the Amudarya river occurs due to an increase in water intake, the river overload is folded below the water intake section, due to frequent discharge of sediments during cleaning into the river floodplain. This led to the deposition and rise of the bed of the canal and the intensive wandering of the stream and, thus, partially affect the displacement of the main stream to the left bank. As a result of a change in the canal profile, the formation of a dumping doctrine, the main canal wanders along a wide floodplain. A meandering canal is formed in the area of the water intake and in the coastal zones of intensive erosion, especially on the right bank of the river below the water intake section at the head structure of the KMC, a deigish is observed.

As a result of these canal processes, erosion of the left bank of the river was observed below the main water intake of the KMC. The erosion area for the period 1991-98 is 200 ... 250 hectares with a strip width of $100 \ldots 300 \mathrm{~m}$. The area of erosion of the floodplain part of the Amudarya River in this area in the zone of the dump current of the coastal territory was $170 \ldots 200$ hectares. The total erosion area is $300 \ldots 450$ hectares. Based on the existing canal situation in the area of the village. Kyzylayak on the rise and fall of the flood in connection with the intensive change in the planned position and deformation of the main canal, an emergency situation may occur, which can lead to destruction of the settlement of Kyzylayak. To prevent this phenomenon, it is necessary to outline priority temporary measures, the construction of a system of short spurs and an embankment house. Considering the high cost of the costs of manufacturing and transporting reinforced concrete products, in the future, it is necessary to strengthen and build dams (spurs), made of local squalls with reinforced concrete structures, only pressure faces and dam heads (spurs). Due to the difficulty in operating the damless water intake, it is clearly seen in the 
KMC on the Amudarya River that the instability of the river canal on the approach to the head structure, which attracted a large amount of sediment into the canals, the lack of flow rates and water levels in dry years and the fall of the winter low water period leads to serious their exploitation. In connection with the difficulty of operating large unaffected water intakes, depending on changes in canal processes and sediment regimes, it is necessary to consider in the future the possibility of transferring the site of the head water intakes to its sovereign territory, or to resolve issues related to ensuring the planned water intake into the main structure of the Main Canal in the future.

Table 1. Average annual volume and intensity of river bank washout along the length and width in the annual section.

\begin{tabular}{|c|c|c|c|c|c|c|}
\hline \multirow{2}{*}{ № } & \multirow{2}{*}{$\begin{array}{l}\text { The name of the area } \\
\text { subject to deformation }\end{array}$} & \multicolumn{3}{|c|}{ Flush strip, $m$} & \multirow{2}{*}{$\begin{array}{l}\text { Flush volume, } \\
\text { thousand } \mathrm{m}^{3}\end{array}$} & \multirow{2}{*}{$\begin{array}{c}\text { Average } \\
\text { annual } \\
\text { washout rate, } \\
\mathrm{cm} / \text { day }\end{array}$} \\
\hline & & length & width & $\begin{array}{l}\text { Height } \\
\text { from the } \\
\text { bottom }\end{array}$ & & \\
\hline 1 & $\begin{array}{l}\text { Pole between left and } \\
\text { middle sleeve }\end{array}$ & 800 & 75 & $3 \ldots 4$ & 210 & 0.20 \\
\hline \multirow[t]{3}{*}{2} & $\begin{array}{l}\text { Extension of the middle } \\
\text { sleeve }\end{array}$ & & & & & \\
\hline & a) first year & 1950 & $100-250$ & $3 \ldots 4$ & 1160 & 0.55 \\
\hline & b) second year & 1900 & 75 & $4 \ldots 5$ & 642 & 0.20 \\
\hline \multirow[t]{3}{*}{3} & $\begin{array}{l}\text { Erosion of the left island } \\
\text { of the right canal at the } \\
\text { water intake point }\end{array}$ & & & & & \\
\hline & a) first year & 300 & 70 & $5 \ldots 6$ & 116 & 0.19 \\
\hline & b) second year & 1500 & $70-600$ & $5 \ldots 6$ & 2475 & 0.82 \\
\hline 4 & $\begin{array}{l}\text { Expansion of the middle } \\
\text { flow below the water } \\
\text { intake point }\end{array}$ & 1300 & 250 & $5 \ldots 6$ & 1788 & 0.68 \\
\hline
\end{tabular}

According to the results of field studies, a formula was established to determine the intensity of river bank washout, depending on the angle of the dump and the hydraulic elements of the flow, can be as follows:

$$
\mathrm{S}=4.6\left(1-\frac{v_{2}^{1.5}}{v_{1}^{1.2}}\right) \cdot \rho_{1} \cdot v_{1} \cdot \sin \alpha_{1}, \quad \mathrm{~m} / \text { day }
$$

where $v_{1}, v_{2}$ - average flow rates at the approach and alignment of the concave river bank; $\rho_{1}-$ turbidity of water on the way to the concave river bank; $\alpha_{1}-$ flow direction angle (stall angle).

To determine the average daily washout rate of the left bank from 19.10 to 23.10 .1983 with the following hydraulic flow elements: average speed $v=0.72 \mathrm{~m} / \mathrm{s}$; average depth $\mathrm{H}=$ 2.2 turbidity $\rho-2.65 \mathrm{~kg} / \mathrm{m} 3$ and flow stall angle $\alpha=300$, observations were carried out, the results of which showed that the intensity of deformation (washout) for the indicated period changed from 4 to $1.17 \mathrm{~m} /$ day. 

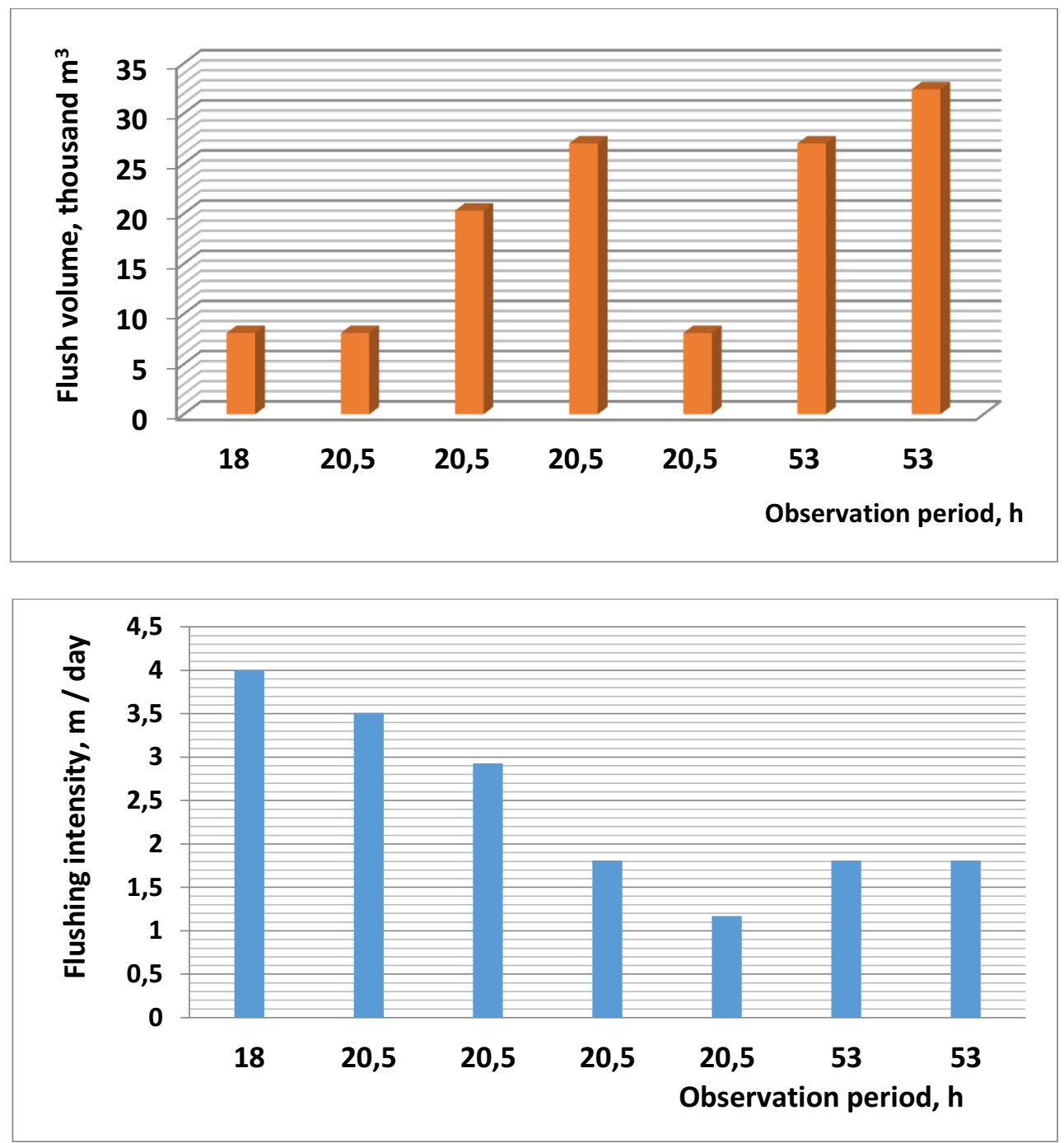

As the experience of the operation of the head structure of the damless water intake shows in the area of water intake in the river bed, there are intense coastal deformations - deigish $[18,19]$.

The rate of destruction of the coast (displacement of its edge) can reach very high values. It should be noted that on the Amu Darya, at low water levels, cases of displacement of the edge of the coast in terms of about $1 \mathrm{~m} /$ day were recorded; at high floods, this rate reached $10-15 \mathrm{~m} /$ day, and in winter, at several elevated levels, $4.0 \mathrm{~m} /$ day. The length of the sections, during which such significant deformations were observed, varied from $0.5-1.5$ to $8-10 \mathrm{~km}$.

In the area of the damless water intake, deigish is observed on the left bank of the Amudarya near the village of Kyzylayak. The appearance of deigish occurs in those cases when there is a significant discrepancy between the bottom topography structure and the flow velocity field. This occurs under conditions of abrupt changes in water and sediment runoff. On the Amudarya rivers, it was possible to identify the following regularity in the runoff of bottom sediments. The river flows through alternating narrowing and widening of the canal. In accordance with this, regular changes in the sign of canal deformations 
constantly occur. In those cases when the predominance of erosion of canal formations appears in the upper sections of the valley expansion, in the lower section of this expansion the canal process acquires an accumulative orientation. The delay of sediments leads to the fact that the narrowing of the canal following the expansion downstream, allows them to pass less and a zone of erosion occurs in the upper part of the next expansion. As the accumulated sediments are worked out in the lower part of the expansion, their runoff along the narrowing increases due to erosion, and signs of accumulation appear in the upper part of the expansion. They disappear as soon as sediment accumulation begins again in the lower part of the next expansion. It is possible to trace that the change in the sign of deformations to the Amudarya River occurs once every 2 years.

Thus, the transport of sediments is carried out by this river in periodically increasing and decreasing portions. It is obvious that the appearance of new canal formations in the river canal causes the diversion of the stream streams, including towards the river bank. If this happens at high levels, local velocities become large (3-4 m/s), which leads to a rapid erosion of the coast. Since the banks of the Amudarya River are usually composed of loess material capable of supporting vertical walls, erosion occurs by a sudden bank collapse.

The most complete picture of the emergence of deigish based on the results of field studies of canal processes and during the development of anti-deygish measures was given by the first academician in the field of canal hydraulics, Professor A.M. Mukhamedov [20].

In the area of the damless water intake at the $\mathrm{KMC}$, due to the inconstancy of flow rates, sharp fluctuations in the water level, high speed of currents and saturation of the flow with bottom and suspended sediments, due to the nature and form of their movement along the bottom, the river bed constantly wanders and the banks are eroded.

According to A.M. Mukhamedov, intensive erosion of the banks of the Amudarya River occurs as a result of the introduction of the main canal by alluvial sediments with a sharp drop in the water level. The introduction of the main canal by sedimentary deposits is explained by the oversaturation of the flow with bottom and bottom sediments due to changes in the velocities of movement of surface and bottom jets.

The aforementioned coastal canal deformations, as a rule, occur in combination with deep deformations (erosion of the bottom or its rise as a result of sedimentation). To obtain sufficiently reliable data on deep deformations, we carried out bottom surveys on a section of the river canal about $5 \mathrm{~km}$ long (Fig. 2) and obtained data on the change in the average bottom over time (intensity of deep deformation) in the investigated section of the river.

From the data presented (Fig. 3), it can be seen that deep deformations in the area of the damless water intake at the KMC occur continuously and are associated with a change in the discharge (water content) and water level. Moreover, during the flood period, an increase in the average bottom is observed [20], although in some of its periods, especially at the beginning of the flood, a slight (in comparison with the rise) decrease is possible, caused by erosion. After the end of the flood period and at the beginning of the low water period, an intensive lowering of the average bottom level begins due to meandering of the canal flow in the easily washed out bed of the river canal. 


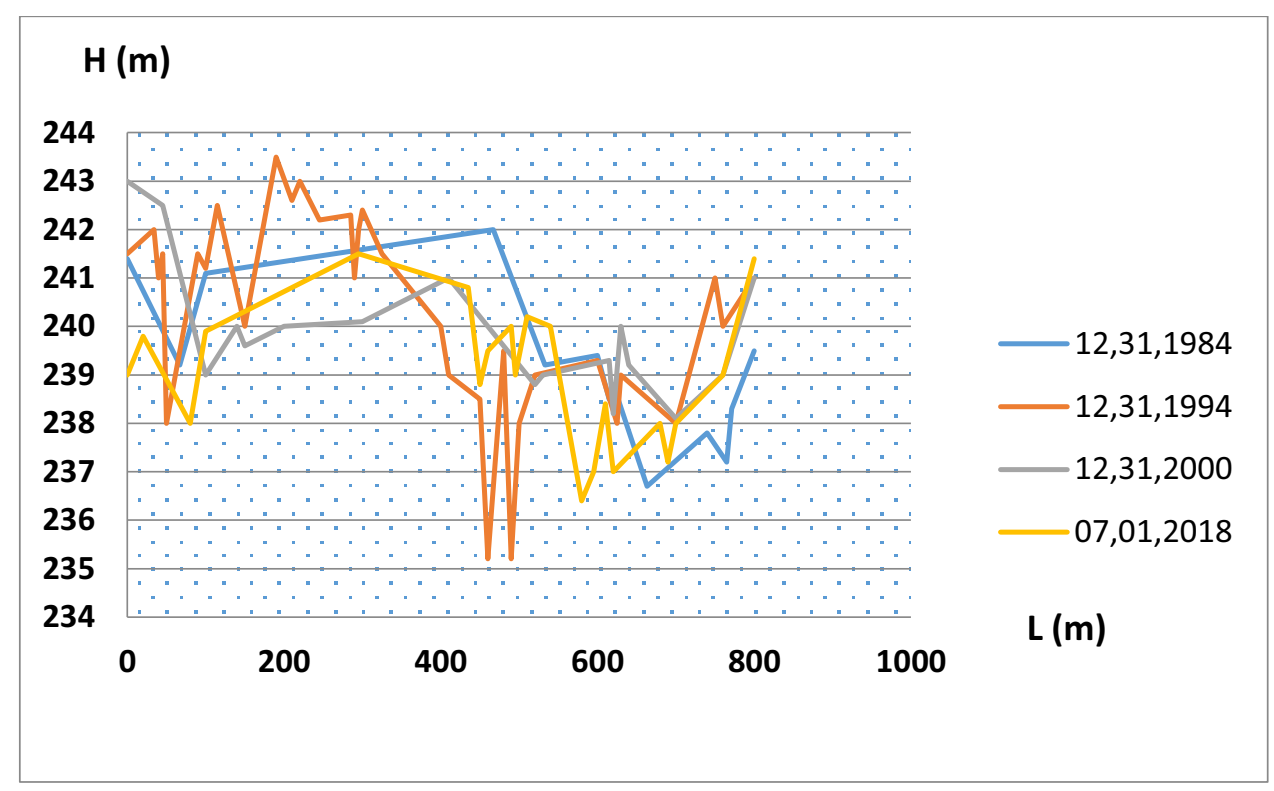

Fig. 3. Intensity of deep deformation of the Amudarya river in the area of the damless water intake at the $\mathrm{KMC}$.

\section{Conclusions}

As the results of the analysis of topographic and space surveys of the river show, the following changes in the planned outline of the river canal took place between the surveys at the head structure in the KMC.

1. As a result of intensive erosion of the sandy island between the middle and right branches over a length of $250 \mathrm{~m}$ (with a flush width of up to $500 \mathrm{~m}$ ), the width of the middle branch increased in the entrance section from 100 to $400 \mathrm{~m}$, and in the section of the connection with the right branch up to $700 \mathrm{~m}$.

2. As a result of the gradual withering away of the left sleeve along which c. $60 \%$ of the discharge flowed in pain, the main river flow began to pass along the middle branch and, joining the right branch, formed a single canal at the approach to the water intake point and downstream, along which up to $90 \%$ of the river flow passed.

3. In the head section of the right branch, the canal was bent, and islands were formed, which impede the flow of significant water flows into the branch, which also contributed to an increase in the water flow passing through the middle branch;

4. The passage of the main discharges along the middle branch caused the erosion of the left bank in the area of the water intake (at a length of $1.5 \mathrm{~km}$, in width up to $600 \mathrm{~m}$ ) and below the water intake, on its right bank (at a length of $1.3 \mathrm{~km}$, in width up to $250 \mathrm{~s}$ ).

5. Due to the sharp change in the water level, the dump of the flow to the left bank and the narrowing of the canal due to cleaning works in the canal of the supply canal, the deigish process continues on the left bank of the Amudarya below the water intake section at the $\mathrm{KMC}$;

6. Due to the intensity of siltation of the supply canal, a decrease in the water level in the river bed and the regulation of the upper course, a sharp deterioration in the conditions of water intake at the KMC is observed. To improve the conditions for water intake at the $\mathrm{KMC}$ and increase the provision of guaranteed planned flow rates of the canal, it is necessary:

7. Maintain great depths in the Amudarya on the approach to the canal entrance; 
8. Systematically carry out canal-adjusting work in the canal of the middle sleeve;

9. To prevent the possibility of withering away of the right bank flow below the water intake point, maintaining it with periodic cleaning and discharging the pulp by working dredgers into the river only during the period of high flood discharge.

\section{References}

1. Bazarov D, Markova I, Norkulov B, Isabaev K, Sapaeva M. Operational efficiency of water damless intake. In: IOP Conference Series: Materials Science and Engineering. Institute of Physics Publishing; 2020.

2. Bazarov D, Markova I, Raimova I, Sultanov S. Water flow motion in the vehicle of main canals. IOP Conf Ser Mater Sci Eng. 2020;883:012001.

3. Bazarov D, Uralov B, Matyakubov B, Vokhidov O. The effects of morphometric elements of the canal on hydraulic resistance of machine canals of pumping stations. Mater Sci Eng. 2020;869(072014).

4. Ikramov N, Majidov T, Kan E, Ikromov I. The height of a damless water intake structure threshold The height of a damless water intake structure threshold. 2020;

5. Krutov A, Bazarov D, Norkulov B, Obidov B, Nazarov B. Experience of employment of computational models for water quality modelling. In: E3S Web of Conferences. EDP Sciences; 2019.

6. Krutov A, Norkulov B, Artikbekova F, Nurmatov P. Optimal location of an intake at a reservoir prone to salt diffusion. IOP Conf Ser Mater Sci Eng. 2020;869:072020.

7. Bazarov D, Shaazizov F, Erjigitov S. Transfer of Amudarya flowing part to increase the supportability of the Uzbekistan southern regions. IOP Conf Ser Mater Sci Eng. 2020;883:012068.

8. Bazarov D, Uralov B, Matyakubov B, Vokhidov O, Uljaev F, Akhmadi M. The effects of morphometric elements of the canal on hydraulic resistance of machine canals of pumping stations. In: IOP Conference Series: Materials Science and Engineering. Institute of Physics Publishing; 2020.

9. Uralov B, Xidirov S, Matyakubov B. River canal deformations in the area of damless water intake River. Mater Sci Eng. 2020;869(072015).

10. Bazarov D, Norkulov B, Vokhidov O, Uljaev F, Ishankulov Z. Two-dimensional flow movement in the area of protective regulatory structures. In: IOP Conference Series: Materials Science and Engineering. Institute of Physics Publishing; 2020.

11. Obidov B, Choriev R, Vokhidov O, Rajabov M. Experimental studies of horizontal flow effects in the presence of cavitation on erosion - free dampers. IOP Conf Ser Mater Sci Eng. 2020;883:012051.

12. Rakhmatov N, Maksudova L, Jamolov F, Ashirov B, Tajieva D. The concept of creating a new water management system in the region. IOP Conf Ser Mater Sci Eng. 2020;883:012007.

13. Obidov B, Vokhidov O, Shodiev B, Ashirov B, Sapaeva M. Hydrodynamic loads on a water drain with cavitation quenchers. IOP Conf Ser Mater Sci Eng. 2020;883:012011.

14. Bazarov D.R. Scientific substantiation of new numerical methods for calculating the deformation of riverbeds composed of easily eroded soils. Moscow; 2000.

15. Artikbekova FK. ESTIMATING THE PROCESSES IN INLET CANAL WITH THE CONSIDERATION OF THE OPERATIONAL FEATURES OF PUMP STATIONS. Tashkent; 2020.

16. Atykbekova F, Uljaev F, Jumaboeva G, Gayur A, Ishankulov Z, Jumanov O. Operation damless intake of the Amudarya river (Central Asia). IOP Conf Ser Mater Sci Eng. 2020;883(1). 
17. Krutov A, Norkulov B, Artikbekova F, Nurmatov P. Optimal location of an intake at a reservoir prone to salt diffusion. In: IOP Conference Series: Materials Science and Engineering. 2020.

18. A.K. K. Sovershenstvovaniye konstruktsiy besplotinnykh vodozabornykh gidrouzlov s donnymi tsirkulyatsionnymi porogami na malykh gornykh rekakh. Publishing House of the Academy of Sciences of the USSR, Moscow; 2015. 155 p.

19. Artykbayeva F., Nishanbayev KH., Sharipov O. O., Azimov S. S. USM. Zatrudneniya ekspluatatsii besplotinnogo vodozabora reki amudar'ya v karshinskiy magistral'nyy kanal. Web Sch [Internet]. 2019;2(6(24)):13-5. Available from: https://wsconference.com/webofscholar

20. Mukhamedov Y.S. MOY. Ruslo- i nanosoreguliruyushchiye meropriyatiya pri vodozabore iz reki Amudar'i v magistral'nyye kanaly (KMK). In: Materialy Resp nauchno-praktich.konf «Problemy i zadachi tselevogo i effektivnogo ispol'zovaniya vodnykh resursov fermerskimi khozyaystvami». Tashkent; 2009. p. 147-50.

21. Mukhamedov Y.S MOY. Bor'ba s nanosami pri vodozabore iz reki Amudar'i (na primere Kashinskogo magistral'nogo kanala). In: Materialy Respublikanskoy nauchno-prakticheskoy konferentsii «Problemy i zadachi tselevogo i effektivnogo ispol'zovaniya vodnykh resursov fermerskimi khozyaystvami». 2009. p. 150-3. 